\title{
POTASSIUM LEAKAGE AND MAIZE SEED PHYSIOLOGICAL POTENTIAL
}

\author{
Mariane Victorio de Carvalho Miguel ${ }^{1,2}$; Julio Marcos Filho ${ }^{1,2 *}$ \\ ${ }^{1}$ Depto. de Produção Vegetal - USP/ESALQ, C.P. 9 - CEP: 13418-900 - Piracicaba, SP. \\ ${ }^{2}$ CNPq Fellow. \\ *Corresponding author <jmarcos@carpa.ciagri.usp.br>
}

ABSTRACT: Seed production usually requires fast decisions to improve the efficacy of seed handling during harvesting, processing and storage. Seed technologists have focused on the development or improvement of procedures which allow rapid and consistent identification of higher quality seed lots. This research verified the effectiveness of the potassium leachate test on the evaluation of the physiological potential of maize seeds in comparison to recommended seed vigor tests. Five seed lots of the hybrid Avant were submitted to the potassium leachate, standard germination, first count, accelerated aging, electrical conductivity, field emergence and cold tests. The amount of potassium leachate was determined after seed imbibition for 30 , $60,90,120,150$ and 180 minutes, at $25^{\circ} \mathrm{C}$; a flame photometer adjusted to $50 \mu \mathrm{g} \mathrm{K}^{+} \mathrm{mL}^{-1}$ pattern and reading 50 was used to determine the amount of leached potassium. The potassium leachate test consistently ranked the seed lots according to their physiological quality in comparison to other tests, and is a new alternative test for maize seed quality control programs.

Key words: Zea mays, seeds, analysis, vigor

\section{LIXIVIAÇÃO DE POTÁSSIO PARA AVALIAÇÃO DO POTENCIAL FISIOLÓGICO DE SEMENTES DE MILHO}

\begin{abstract}
RESUMO: A necessidade freqüente da tomada de decisões rápidas, principalmente nas etapas de colheita, processamento e comercialização é habitual durante o processo de produção de sementes de várias espécies, dentre elas o milho. Consequentemente, a pesquisa em tecnologia de sementes tem procurado desenvolver ou aperfeiçoar testes que possibilitem avaliar, com eficiência, o potencial fisiológico das sementes, em período de tempo relativamente curto. O presente trabalho teve como objetivo verificar a potencialidade do teste de lixiviação de potássio, para avaliação do vigor de sementes de milho; cinco lotes do híbrido Avant foram submetidos a esse teste, cuja eficiência foi comparada à dos testes de germinação, primeira contagem de germinação, envelhecimento acelerado, frio, condutividade elétrica e emergência de plântulas em campo, recomendados para sementes de milho. A quantidade de potássio exsudado foi determinada em fotômetro de chama (padrão $50 \mu \mathrm{g} \mathrm{K}^{+} \mathrm{mL}^{-1}$ ajustado para leitura 50), após 30, 60, 90, 120, 150 e 180 minutos de embebição, a $25^{\circ} \mathrm{C}$. O teste de lixiviação de potássio foi considerado eficiente para separação dos lotes em diferentes níveis de vigor, constituindo alternativa promissora para avaliação do potencial fisiológico de sementes de milho; essa possibilidade contribui para a obtenção rápida de informações balizadoras de programas de controle de qualidade pós-colheita.
\end{abstract}

Palavras-chave: Zea mays, sementes, análise, vigor

\section{INTRODUCTION}

Seed production usually requires fast decisions to improve the efficacy of seed handling during harvesting, processing, storage and commercialization. Seed technologists have focused on the development or improvement of procedures which allow rapid and consistent identification of higher quality seed lots. Seed germination has been considered less effective to monitor seed quality control programs, since this test does not adequately estimate deterioration level, storability and seedling emergence under moderately unfavorable or stressful field conditions.

Seed vigor testing has reached increasing importance to rank seed lots according to their physiological potential. One of the main concerns regarding seed vigor evaluation is obtaining reliable results within a short time for quality control programs. Literature shows that available rapid seed vigor tests which produce consistent information on seed physiological potential are those associated with the determination of enzymatic and respiratory activities and cell membrane integrity such as the tetrazolium and electrical conductivity tests, respectively (Abdul-Baki \& Baker, 1973).

The electrical conductivity test is acknowledged as one of the best tests for the evaluation of the loss of cell membrane integrity by the concentration of electrolytes released by seeds during imbibition; cell membrane integrity is considered one of the primary physiological events of seed deterioration process (Delouche, 1976); consequently, lower vigor seed lots exhibit higher intensity of cellular constituent losses, such as inorganic ions. However, relatively few studies have aimed determining which specific cations are leached from an imbibing seed (Webes and Karssen, 1990). Researchers have not focused on maize seeds to clarify this doubt so far. 
Potassium has been shown to be the main ion leached by seeds during imbibition, followed by sodium and calcium, and may be used as an indicator of cell membrane integrity (Halloin, 1975). The potassium leachate test is based on the same principle of the electrical conductivity test with the additional advantage of producing results in a considerable shorter period of time. In addition, it focus on a specific ion, while the electrical conductivity test evaluates a set of electrolytes release (Panobianco \& Marcos-Filho, 2001a).

Simon \& Raja-Harun (1972) and Halloin (1975) determined the leakage intensity during imbibition of pea and cotton seeds, respectively, and verified a strong relation between the results of the electrical conductivity test and the amount of potassium leached by seeds. Woodstock et al. (1985) concluded that the potassium and calcium leakage from cotton seeds were promising as assessment indexes of seed physiological potential, emphasizing that potassium leachate results were more consistent than those of the electrical conductivity test. Literature has shown that the potassium leakage may be used as an indicator of cell membrane integrity as reported by McKersie \& Stinson (1980); Webes \& Karssen (1990); Dias et al. (1996); Custódio \& MarcosFilho (1997).

Marcos-Filho et al. (1982) found significant correlation between results of potassium leachate and germination, first count and accelerated aging tests, and concluded that the potassium leachate test provides reliable information on the characterization of the maturation process and on the evaluation of soybean seed vigor. In contrast, Marcos-Filho et al. (1984) and Barros \& Marcos Filho (1988) did not obtain consistent results with this methodology.

Studies to refine the procedures of this test, including flame photometer calibration, water volume and imbibition period, temperature, sample size and presentation of results, turned the determination of potassium released from seeds during imbibition a promising alternative for the assessment of seed vigor of different species as reported by Barros et al (1999) for field bean, and Panobianco \& Marcos-Filho (2001) for tomato seeds.

Research efforts related to the potassium leachate and electrical conductivity tests have been directed to dicotyledonous seeds. Maize seed vigor is usually evaluated by the cold and accelerated aging tests, but seed industry requires information on seed physiological potential to be drawn in a considerable shorter time. Consequently, the main objective of this research was to investigate the potential use of the potassium leachate test for the determination of maize seed vigor.

\section{MATERIAL AND METHODS}

This research was conducted at the USP/ESALQ/ Crop Production seed laboratory, in Piracicaba, SP,
Brazil, with five seedlots of Avant hybrid cultivar. The use of different seed lots is justified as a tentative to detect narrow and wider differences in seed vigor as evaluated by the potassium leachate test. Germination of seed lots was superior to the minimum standards required for marketing maize seeds (85\%).

On receipt, each lot was blended periodically to assure uniformity and stored in multi-layered bags under normal, ambient laboratory conditions during the experimental period. The following determinations were made:

Seed water content: Was determined at $105+3^{\circ} \mathrm{C}$ for $24 \mathrm{~h}$ in duplicate samples of intact seeds as recommended by the Rules for Testing Seeds (Brasil, M.A., 1992). The results were expressed as percentage water content (fresh weight basis).

Germination test: Performed on four 50 -seed replicates planted in rolled paper towels moistened to the equivalent 2.5 times the substratum weight and germinated at $25^{\circ} \mathrm{C}$. Seedling counts were conducted at four and seven days after seeding, evaluated for normal development, and results were expressed as percent normal seedlings for each lot (Brasil, M.A., 1992).

Germination first count: Was performed simultaneously to the germination test and percent normal seedlings was recorded four days after seeding.

Accelerated aging: A single layer of seeds of each lot was placed on a wire mesh screen and suspended over $40 \mathrm{~mL}$ of water inside a plastic accelerated aging box (MarcosFilho, 1999b). Boxes were held at $41^{\circ} \mathrm{C}$ and $100 \%$ relative humidity for $96 \mathrm{~h}$ in an incubator. After this aging period, four replicates of 50 seeds each were tested for germination as described. The evaluation of seedling development was made four days after seeding, and the mean normal seedling percentage per lot determined. Seed water content (oven method at $105^{\circ} \mathrm{C} / 24 \mathrm{~h}$ ) was also determined before and after the aging period to evaluate the accuracy of the accelerated aging results.

Electrical conductivity: The electrical conductivity of the leachate from whole imbibed seeds was determined on four replications of 50 seeds (not selected for damaged seed coats) each weighed to the nearest $0.01 \mathrm{~g}$, placed in plastic cups with $75 \mathrm{~mL}$ distilled water, and held in a germinator at $25^{\circ} \mathrm{C}$. After $24 \mathrm{~h}$, the electrical conductivity of leachates was determined.

Cold test: Four replicates of 50 seeds per lot were planted in plastic boxes $(60 \times 30 \times 10 \mathrm{~cm})$; substratum was a mixture parts sand and 1 part soil from area previously cultivated with maize). The seedbed water content was adjusted to $60 \%$ water holding capacity. Upon seeding, the plastic boxes were maintained at $10^{\circ} \mathrm{C}$ for seven days, and then transferred to a germinator at $25^{\circ} \mathrm{C}$ for four days. The results were expressed in percent emerged seedlings per seed lot (Marcos Filho et al., 1987). 
Potassium leakage: Four replicates of 50 seeds per lot weighed to the nearest $0.01 \mathrm{~g}$ were placed in disposable plastic cups with $75 \mathrm{~mL}$ distilled water and held in a germinator at $25^{\circ} \mathrm{C}$. After $30,60,90,120,150$, and 180 minutes imbibition periods the amount of leached potassium was determined in aliquots of $5 \mathrm{~mL}$ withdrawn from each sample, by a flame photometer adjusted to the $50 \mu \mathrm{g} \mathrm{K}^{+} \mathrm{mL}^{-1}$ and reading 50 (Carvalho et al., 1999). Results were expressed in $\mu \mathrm{g} \mathrm{K}^{+} \mathrm{g}^{-1}$ seeds.

Field seedling emergence: Four replicates of 100 seeds each per seed lot were distributed in $4.0 \mathrm{~m}$ long furrows, $0.5 \mathrm{~m}$ apart and $0.03 \mathrm{~m}$ deep, holding soil sufficiently wet for germination. Emerged seedlings were counted 15 days after planting and the mean percentage determined for each lot.

Statistical analysis: The statistical analysis was conducted separately for each test and the treatments distributed in a completely randomized design $(n=4)$. Statistical Analysis System - SANEST (Zonta \& Machado, 1984) and the multiple mean comparison by Tukey's test $(p<0.05)$ were used as statistical tools.

\section{RESULTS AND DISCUSSION}

Seed vigor comprises those seed properties which determine the potential for rapid, uniform emergence and development of normal seedlings under a wide range of field conditions (AOSA, 1983). Recently, TeKrony emphasized that seed vigor testing must rank seed lots of commercially accepted germination.

Although germination and vigor are closely associated, seed vigor is highly complex compared to standard germination and provides additional information to assist in differentiation of the physiological potential of seed lots, seed storability and potential field performance. It is desirable that practical vigor tests consider rapidity, simplicity, objectivity, reproducibility of test results, and relationship with seedling emergence.

However, tentative to detect differences in vigor among seed lots possessing wide variation in germination percentage is not reasonable; it must be considered that if the germination test identifies different performance of seed lots under favorable environmental conditions, the use of vigor tests would not provide significant practical information. For this reason, since a valuable vigor test should offer a better estimation of physiological potential of high germinating seed lots, germination range of seed lots used in this research was from $88 \%$ to $98 \%$, thus allowing for the evaluation of sensitiveness of potassium leachate test as compared to other vigor tests recommended for maize seeds, mainly to the electrical conductivity test that also indirectly evaluates cell membrane integrity.

Seed water content prior to testing ranged from $8.4 \%$ to $8.9 \%$ among seed lots. Therefore, this parameter did not significantly affected seed performance during germination and vigor testing (Delouche, 1976; Matthews, 1981; Loeffler et al., 1988; Krzyzanowski et al., 1991; Vieira \& Carvalho, 1994; Marcos-Filho, 1999b).

Water contents of seeds exposed to accelerated aging ranged from $20.2 \%$ to $22.2 \%$, indicating that temperature and relative humidity control in the outer accelerated aging chamber (B.O.D.) was precise enough to assure consistent results (Krzyzanowski et al., 1991; Marcos Filho, 1999b). Values recorded for seed water content after aging were lower than those reported for maize seeds by Hampton \& TeKrony (1995), who considered the combination $45^{\circ} \mathrm{C} / 72 \mathrm{~h}$ for the accelerated aging test, whereas $41^{\circ} \mathrm{C} / 96 \mathrm{~h}$ was used herein. Marcos-Filho (1999b) considered that a deviation of $3-4 \%$ water content among seed samples after aging is tolerable once it does not significantly affects accelerated aging results.

Table 1 shows that all vigor tests ranked seed lots regarding physiological potential but have different sensitivity to detect seed vigor level. Germination test results demonstrated that all seed lots were positioned within the initial phase of the survival curve, in which germination remains high and exhibits slow decrease (Powell, 1986).

Seed germination of lots 1 and 4 was significantly higher than lots 3 and 5 ; lot 2 was identified as intermediate quality by this test. Germination first count and cold tests results were similar to germination test. On the other hand, electrical conductivity and seedling emergence confirmed lots 1 and 4 as having the highest quality. However, lot 2, exhibited lower performance potential in comparison to lots 3 and 5 (Table 1).

Information drawn from accelerated aging test was comparable to information produced by germination, first count, electrical conductivity and seedling emergence tests. However, only seed physiological potential of lot 1 was identified as having better performance; lot 3 showed the lower quality whereas lots 2 and 5 were intermediate in vigor.

Germination and vigor tests provided similar information regarding physiological potential and this similarity was evidenced for higher quality seed lots. Identification of intermediate vigor seed lots is still a challenge for seed testing research, once results frequently overlap higher and/or lower vigor lots, depending on the test performed. This is a common observation, specially when seed lots possess narrow quality differences (McDonald \& Wilson, 1979; Kulik \& Yaklich, 1982; Marcos Filho et al., 1984; 1986). It is thus advisable that efficient vigor tests for seed industry must reveal differences in performance between high and low physiological potential seed lots.

To date, no vigor test is considered acceptable for all crops: even considering specific crop, seed quality tests must be sufficiently versatile to measure a set of factors compromising seed performance in the field or during storage in a wide range or stressful environmental 
conditions. Marcos-Filho (1998) suggested a combination of results from several vigor tests to attain precise identification of physiological potential of seed lots. Seed vigor and seed deterioration are reciprocal depending on the properties of the seed or the seed lot. In fact, seed vigor manifestation is closely dependent on deterioration level, on factors affecting seed deterioration process, specific characteristics evaluated by vigor tests and procedures adopted for vigor evaluation (Woodstock, 1973; TeKrony \& Egly, 1977; Carvalho \& Nakagawa, 2000).

All procedures compared in the potassium leachate test were effective to detect differences among seed lots. Lots 1 and 4 had the best and lots 2, 3 and 5 the worst performance (Table 2). This test provided information comparable to the other vigor tests performed here, with the significant advantage of rapidity (30 minutes imbibition). The electrical conductivity test, based on the same principle, provides results only after a $24 \mathrm{~h}$ imbibition period when performed under current procedure (AOSA, 1983). Woodstock et al. (1985) reported that evaluation of potassium and calcium released during seed imbibition were better indexes for vigor assessment than total electrolytes by the electrical conductivity test.

Potassium leachate and electrical conductivity tests yielded similar results in the ranking of physiological potential of seed lots. Main difference between these tests was the rapidity to provide information. It was also verified smaller variation among replicates for potassium leachate results, what would enhance standardization of this test for maize seeds.

Simon \& Raja-Harun (1972) e Halloin (1975) have already found the similarities between results of potassium leachate and electrical conductivity tests, although Simon \& Raja-Harun have not used these parameters as seed vigor tests. In contrast, Marcos-Filho et al. (1984) and Barros \& Marcos-Filho (1988) did not succeed on assessing soybean seed vigor by the potassium leachate test.

Results of this research confirmed those of Woodstock et al. (1985), Dias et al. (1996), Custodio \& Marcos-Filho (1997), Barros et al. (1999) and Panobianco \& Marcos-Filho (2001) who considered that the evaluation of one specific ion by the potassium leachate test produced more consistent than electrical conductivity test. Consequently, the objectives of this research were attained as the potential use of the potassium leachate test for maize seed vigor testing was confirmed. In addition, this test presents additional advantages in regard to rapidity that allow prompt decisions in seed quality control programs. However, procedures test are not yet completely standardized, requiring additional research.

The precisely of adequate sample size, water volume for seed imbibition, temperature and imbibition period must be defined for different seed genotypes, since the precisely of the combination among those parameters is essential to produce consistent results. In

Table 1 - Mean values from seed germination, first count, accelerated aging, seedling emergence and cold tests of five maize seed lots, cultivar Avant.

\begin{tabular}{ccccccc}
\hline Seed lots & Germination & First count & $\begin{array}{c}\text { Accelerated } \\
\text { aging }\end{array}$ & Cold test & $\begin{array}{c}\text { Seedling } \\
\text { emergence }\end{array}$ & $\begin{array}{c}\text { Electrical } \\
\text { conductivity }\end{array}$ \\
\hline 1 & $98 \mathrm{a}^{*}$ & $97 \mathrm{a}$ & $87 \mathrm{a}$ & $90 \mathrm{a}$ & $99 \mathrm{a}$ & $16.53 \mathrm{a}$ \\
2 & $92 \mathrm{ab}$ & $89 \mathrm{ab}$ & $69 \mathrm{bc}$ & $85 \mathrm{ab}$ & $89 \mathrm{~b}$ & $31.15 \mathrm{~b}$ \\
3 & $88 \mathrm{~b}$ & $86 \mathrm{~b}$ & $62 \mathrm{c}$ & $77 \mathrm{~b}$ & $86 \mathrm{~b}$ & $41.15 \mathrm{~b}$ \\
4 & $98 \mathrm{a}$ & $97 \mathrm{a}$ & $82 \mathrm{ab}$ & $91 \mathrm{a}$ & $98 \mathrm{a}$ & $14.91 \mathrm{a}$ \\
5 & $89 \mathrm{~b}$ & $88 \mathrm{~b}$ & $71 \mathrm{bc}$ & $79 \mathrm{~b}$ & $89 \mathrm{~b}$ & $42.50 \mathrm{~b}$ \\
\hline C.V. (\%) & 3.7 & 4.0 & 8.5 & 6.0 & 5.9 & 20.0 \\
\hline
\end{tabular}

*Means comparison within each column (Tukey's test, $p<0.05$ )

Table 2 - Mean values from potassium leachate test of five maize seed lots, cultivar Avant, in each imbibition period.

\begin{tabular}{|c|c|c|c|c|c|c|}
\hline \multirow{2}{*}{ Seed lots } & \multicolumn{6}{|c|}{ Imbibition periods (min) } \\
\hline & 30 & 60 & 90 & 120 & 150 & 180 \\
\hline & \multicolumn{6}{|c|}{ 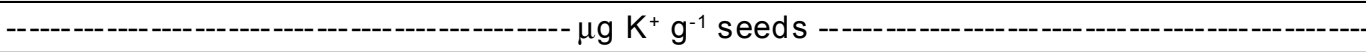 } \\
\hline 1 & $66.58 \mathrm{a}$ & 76.90 a & $85.74 \mathrm{a}$ & $93.24 \mathrm{a}$ & 99.45 a & $107.51 \mathrm{a}$ \\
\hline 2 & $199.13 \mathrm{~b}$ & $216.87 \mathrm{~b}$ & $239.33 b$ & $246.58 b$ & $25.27 b$ & $264.10 b$ \\
\hline 3 & $215.43 b$ & $230.51 b$ & $238.32 b$ & $243.08 \mathrm{~b}$ & $247.59 \mathrm{~b}$ & $252.00 \mathrm{~b}$ \\
\hline 4 & $65.14 \mathrm{a}$ & $73.17 \mathrm{a}$ & 82.05 a & 90.64 a & $93.64 \mathrm{a}$ & $102.81 \mathrm{a}$ \\
\hline 5 & $188.95 b$ & 217.72 b & $230.95 b$ & $242.35 b$ & $252.02 b$ & $253.62 b$ \\
\hline C.V. (\%) & 4.9 & 5.8 & 4.7 & 6.4 & 5.5 & 5.2 \\
\hline
\end{tabular}

${ }^{*}$ Means comparison within each column (Tukey's test, $p<0.05$ ) 
addition, the evaluation of a wide number of maize seed lots, as a referee test, and seed analysts training are crucial steps towards the improvement of this alternative and its adoption by seed industry.

\section{CONCLUSION}

The potassium leachate test is an efficient alternative to assess maize seed vigor, providing rapid and consistent information. The combination of 50 pure seeds imbibed in $75 \mathrm{~mL}$ distilled or deionized water at $25^{\circ} \mathrm{C}$ for 30 minutes represents the most accurate procedure to rank maize seed lots according to their physiological potential.

\section{REFERENCES}

ABDUL-BAKI, A.A.; BAKER, J.E. Are changes in cellular organelles or membranes related to vigor loss in seeds. Seed Science and Technology, v.1, p.89-125, 1973.

ASSOCIATION OF OFFICIAL SEED ANALYSTS. Seed vigour testing handbook. East Lansing: AOSA, 1983. 93p. (Contribution, 32).

BARROS, A.S.R.; MARCOS FILHO, J. Testes para avaliação rápida da viabilidade de sementes de soja. Pesquisa Agropecuária Brasileira, v.25, p.1447-1459, 1988.

BARROS, M.A.; OHSE, S.; MARCOS FILHO, J. Ion leakage as an indicator of vigor in field bean seeds. Seed Technology, v.21, p.44-48, 1999.

BRASIL. Ministério da Agricultura. Regras para análise de sementes. Brasília: SNAD, DNDV, CLAV, 1992. 365p.

CARVALHO, M.V.; SPINOLA, M.C.M; MARCOS FILHO, J. Lixiviação de potássio na avaliação da qualidade fisiológica de sementes de milho In: CONGRESSO BRASILEIRO DE SEMENTES, 11., Foz do Iguaçu, 1999. Anais. Curitiba: ABRATES, 1999. p.130.

CARVALHO, N.M.; NAKAGAWA, J. Sementes: ciência, tecnologia e produção. Jaboticabal: FUNEP, 2000. 588p.

CUSTÓDIO, C.C.; MARCOS FILHO, J. Potassium leakage test for the evaluation of soybean seed physiological quality. Seed Science and Technology, v.25, p.549-564, 1997.

DELOUCHE, J.C. Standardization of vigor tests. Journal of Seed Technology, v. 1, p.75-86, 1976

DIAS, D.C.F.S.; MARCOS FILHO, J.; CARMELLO, Q.A.C. Potassium leakage test for the evaluation of vigour in soybean seeds. Seed Science and Technology, v.25, p.7-18, 1996

HAMPTON, J.G.; TeKRONY, D.M. (Ed.) Handbook of vigour test methods. Zurich: International Seed Testing Association, 1995. 117p.

HALLOIN, J.M. Solute loss from deteriorated cotton seed: relationship between deterioration, seed moisture, and solute loss. Crop Science, v.15, p.1115, 1975.

KRYZANOWSKI, F.C.; FRANÇA NETO, J.B.; HENING, A.A. Relato dos testes de vigor disponíveis para as grandes culturas. Informativo ABRATES, v.1, p.15-50, 1991

KULIK, M.M; YAKLICH, R.W. Evaluation for vigor tests in soybean seeds relationship of accelerated aging, cold, sand bench and speed of germination tests to field performance. Crop Science, v.22, p.766-770, 1982.

LOEFFLER, T.M.; TEKRONY, D.M.; EGLI, D.B. The bulk conductivity test as an indicator of soybean seed quality. Journal of Seed Technology, v.12, p.37-53, 1988.
MARCOS FILHO, J. O valor dos testes de vigor. Seed News, n.6, p.32, 1998

MARCOS FILHO, J. Testes de vigor: importância e utilização. In: KRZYZANOWSKI, F.C.; VIEIRA, R.D.; FRANÇA NETO, J.B. (Ed.) Vigor de sementes: conceitos e testes. Londrina: ABRATES, 1999a. cap.1, p.1-21.

MARCOS FILHO, J. Teste de envelhecimento acelerado. In: KRZYZANOWSKI, F.C.; VIEIRA, R.D.; FRANÇA NETO, J.B. (Ed.) Vigor de sementes: conceitos e testes. Londrina: ABRATES, 1999b. cap.3, p.1-24.

MARCOS FILHO, J.; CICERO, S.M.; SILVA, W.R. Avaliação da qualidade de sementes. Piracicaba: FEALQ, 1987. 230p.

MARCOS FILHO, J.; AMORIM, H.V.; SILVAROLLA, M.B.; PESCARIN, H.M.C. Relações entre germinação, vigor e permeabilidade das membranas celulares durante a maturação de sementes de soja. In: SEMINÁRIO NACIONAL DE PESQUISA DE SOJA, 2., Brasilia, 1981. Anais. Londrina: EMBRAPA/CNPSo, 1982. p.676-683.

MARCOS FILHO, J.; CARVALHO, R.V.; CICERO, S.M.; DEMÉTRIO, C.G.B. Qualidade fisiológica e comportamento de sementes de soja no armazenamento e no campo. Anais da ESALQ, v.43, p.389-443, 1986.

MARCOS FILHO, J; PESCARIN, H.M.C.; KOMATSU, Y.H: DEMÉTRIO, C.G.B.; FANCELLI, A.L. Testes para avaliação do vigor de sementes de soja e sua relação com emergência de plântulas em campo. Pesquisa Agropecuária Brasileira, v.19, p.605-613, 1984.

MATTHEWS, S. Evaluation of techniques for germination and vigor studies. Seed Science and Technology, v.9, p.543-551, 1981.

McDONALD, M.B.; WILSON, D.O. An assessment of the standardization and ability of the ASA-610 to rapidly predict potential soybean germination. Journal of Seed Technology, v.4, p.1-11, 1979.

McKERSIE, B.D.; STINSON, R.H. Effect of dehydration on leakage and membrane structure in Lotus maizeiculatus L. seeds. Plant Physiology, v.66, p.316-320, 1980

PANOBIANCO, M.; MARCOS FILHO, J. Avaliação do potencial fisiológico de sementes de tomate através de testes de germinação e de vigor. Informativo ABRATES, v.11, p.179, 2001.

PANOBIANCO, M.; MARCOS FILHO, J. Evaluation of the physiological potential of tomato seeds by germination and vigor tests. Seed Technology, v.23, p.149-159, 2001.

POWELL, A.A. Cell membranes and seeds leachate conductivity in relation to the quality of seed for sowing. Journal of Seed Technology, v.10, p.81-100, 1986 .

SIMON, E.W.; RAJA-HARUN, R.M. Leakage during seed imbibition. Journal of Experimental Botany, v.23, p.1076-1085, 1972.

TeKRONY, D.M. PRECISION: An essential component in seed vigor testing In: INTERNATIONAL SEED TESTING ASSOCIATION CONGRESS SEED SYMPOSIUM, 26., Angers, França, 2001. Abstracts. Zurich: ISTA, 2001. p.14.

TeKRONY, D.M.; EGLI, D.B. Relationship between laboratory indices of soybean seed vigor and field emergence. Crop Science, v.17, p.573$577,1977$.

VIEIRA, R.D.; CARVALHO, N.M. Testes de vigor em sementes. Jaboticabal: FUNEP, 1994. 164p.

WEBES, R.; KARSSEN, C.M. The influence of redesiccation on dormancy and $\mathrm{K}^{+}$leakage of primed lettuce seeds. Israel Journal of Botany, v.39, p.327-336, 1990.

WOODSTOCK, L.W. Physiological and biochemical tests for seed vigor. Seed Science and Technology, v.1, p.127-157, 1973.

WOODSTOCK, L.W.; FURMAN, K.; LEFFLER, H.R. Relationship between weathering deterioration and germination, respiratory metabolism, and mineral leaching from cotton seeds. Crop Science, v.25, p.459-466, 1985.

ZONTA, E.P.; MACHADO, A.A. Sistema de análise estatística para microcomputadores - SANEST. Pelotas: UFPel, 1984.

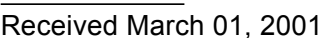

